\title{
LETTERS
}

\section{An Autosomal Recessive Nonsyndromic Form of Sensorineural Hearing Loss Maps to 3p-DFNB6}

\author{
Kunihiro Fukushima, ${ }^{1}$ Arabandi Ramesh, ${ }^{2}$ C.R. Srikumari Srisailapathy, ${ }^{2}$ \\ Li Ni, ${ }^{1}$ Sigrid Wayne, ${ }^{1}$ Marsha E. O'Neill,, Guy Van Camp, ${ }^{3}$ \\ Paul Coucke, ${ }^{3}$ Pawan Jain, ${ }^{4}$ Edward R. Wilcox, ${ }^{4}$ Shelley D. Smith, ${ }^{5}$ \\ Judith B. Kenyon, ${ }^{5}$ Ross I.S. Zbar, ${ }^{1}$ and Richard J.H. Smith ${ }^{1,6}$
}

${ }^{1}$ Molecular Otolaryngology Research Laboratories, Department of Otolaryngology, University of lowa, lowa City, lowa 52242; ${ }^{2}$ Department of Genetics, University of Madras, Madras, India; ${ }^{3}$ Department of Medical Genetics, University of Antwerp (UIA), 2610 Antwerpen, Belgium; ${ }^{4}$ National Institute on Deafness and Other Communication Disorders, National Institutes of Health, Rockville, Maryland 20850;

${ }^{5}$ Boys Town National Research Hospital, Omaha, Nebraska 68131

Autosomal recessive nonsyndromic hearing loss (ARNSHL) is the most common form of congenitally acquired inherited hearing impairment. Although numerous loci are believed to exist, only five have been identified. Using a pooled genomic DNA screening strategy, we have identified a sixth locus, DFNB6, on 3p in the interval bounded by D3S1619 and D3S1766.

Autosomal recessive nonsyndromic hearing loss (ARNSHL) is the most common type of inherited hearing impairment (Bergstrom et al. 1971). Although almost exclusively monogenic, it is highly heterogeneous with some estimates of the number of gene loci exceeding 100 (Chung and Brown 1970). Only five loci have been identified (Guilford et al. 1994a,b; Baldwin et al. 1995; Friedman et al. 1995; Fukushima et al. 1995), however, as affected families cannot be pooled and single nonconsanguineous families rarely are informative enough to obtain linkage. Recently, we proposed simultaneous analysis of multiplex sibships of consanguineous unions as a mapping strategy to exploit the heterogeneity of ARNSHL for gene localization (Fukushima et al. 1995). The hearing-impaired progeny of a consanguineous union are expected to share a region of many centimorgans (cM) around the disease locus that is homozygous by descent-other genomic regions also are homozygous by descent but vary from one child to next. For this strategy to be successful, highly informative polymorphic

${ }^{6}$ Corresponding author.

E-MAIL richard-smith@uiowa.edu; FAX (319)356-4547. markers must be used to minimize the falsepositive rate (estimated at 5\%; Fukushima et al. 1995), and powerful algorithms and software must be available to perform linkage calculations within reasonable time periods (Kruglyak et al. 1995).

\section{RESULTS}

Single alleles were demonstrated in two of nine families using D3S1767. Two other markers tightly linked to D3S1767 (D3S1619 and D3S1289) did not shown allelic homozygosity in one of these families. In the remaining family, homozygosity by descent was demonstrated in the parents over an interval of 19-22 cM. From the affected progeny, the location of DFNB6 was mapped to the 14- to 20-cM interval bounded by D3S1619 and D3S1766 ( $\hat{\mathrm{Z}}=3.3$; Fig. 1).

\section{DISCUSSION}

This region is the site of several genes that could be essential for normal auditory function, including zinc finger protein 35 (Calabro et al. 1995), $\beta$-catenin (CTNNB1; Bailey et al. 1995), guanine 
FUKUSHIMA ET AL.
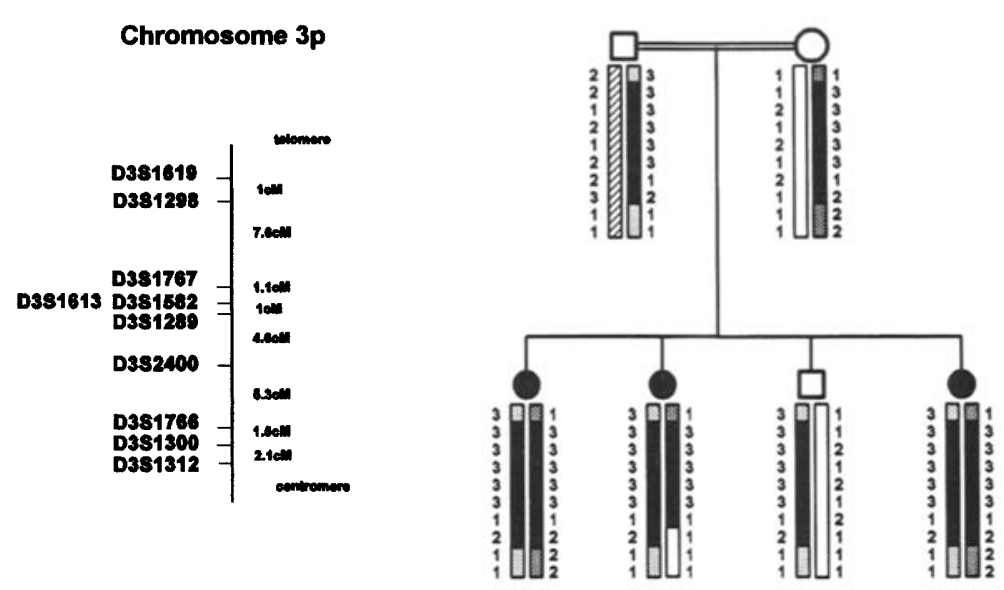

\begin{tabular}{|c|c|c|c|}
\hline Locus & Allowe & skes & Allobe Froquency \\
\hline D9S1208 & 3 & 1986p & 0.0841 \\
\hline Das1787 & 3 & 250bp & 0.1164 \\
\hline D3s 1613 & 3 & 297bp & 0.1210 \\
\hline D3S1682 & 3 & 164bp & 0.1024 \\
\hline D3S1289 & 3 & 192bp & 0.1206 \\
\hline D3s2400 & 1 & 218bp & 0.1292 \\
\hline
\end{tabular}

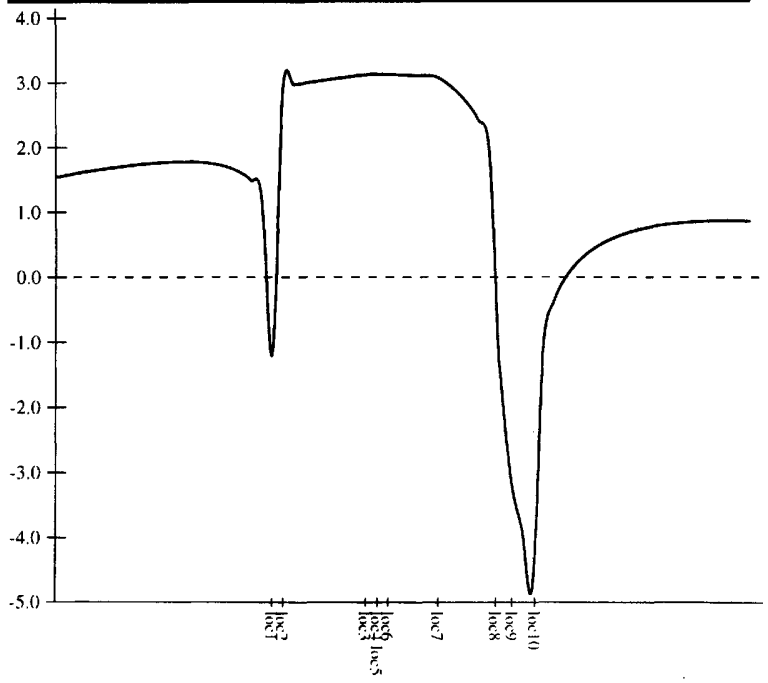

Figure 1 Homozygosity by descent in a second cousin marriage localizing a gene for ARNSHL (DFNB6) to the interval flanked by

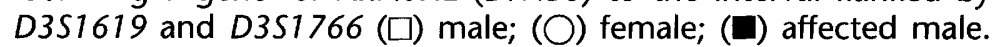
Allele frequencies are calculated in the population under study.

sion of LQT-3 in a fetal-derived cochlear-specific cDNA library (R.J.H. Smith, unpubl.). A possible animal model of DFNB6 is the spinner (sr) mouse mutant (Fox et al. 1978), which as a homozygote exhibits signs of defective hearing and shows the typical head tossing, circling, deafness, and hyperactivity of the Shaker-Waltzer mutants. Inner ear abnormalities in the $s r / s r$ homozygote include degeneration of the organ of Corti and spiral ganglion, reduction in size of the stria vascularis, and degeneration of the saccular macula (Deol and Robbins 1962).

\section{METHODS}

A total of 54 unrelated simplex and multiplex families with probable ARNSHL have been ascertained by identifying probands from four schools for the deaf (St. Louis Institute for the Deaf and the Blind, CSI School for the Deaf, Little Flower Covenant School for the Deaf and Bala Vidyalaya School for the Deaf) and from the Institute of Basic Medical Sciences in Madras, India, the capital city of Tamil Nadu. Audiograms and data on age at onset of hearing loss were gathered through repeated household visits. Affected persons had congenital prelingual severe to profound hearing loss, and in most instances, demonstrated no response to auditory testing at equipment limits (Maico Pure Tone Audiometer). Conditions such as rubella, prematurity, drug use during pregnancy, perinatal trauma, sudden infant death syndrome, and meningitis were eliminated by history.

The biological relationship between spouses was determined by extensive questioning and verified by elderly members of the household. A subset of 26 families with two or more affected siblings was considered for possible homozygosity mapping. Within this subset, there were 11 first cousin unions, 7 uncleniece unions, and 8 second cousin unions. The calculated maximal LOD score for individual families ranged from 1.8 to 4.53 , nine families generated LOD scores of $>3$, and in two other

nucleotide-binding protein $\alpha$-transducing polypeptide-1 (GNAT-1; Wilkie et al. 1992), laminin $S$ (LAMS; R. Vuolteenaho, M. Nissinen, R.L. Eddy, T.B. Shows, and K. Tryggvason, pers. comm.), dystrophin-associated glycoprotein-1 (DAG; Ibraghimov-Beskrovnaya et al. 1992), long (electrocardiographic) QT syndrome-3 (LQT-3; Jiang et al. 1994), and SYNII (Li et al. 1995). Although the last two are intriguing as candidate genes for DFNB6, we have not been able to confirm expres- families, LOD scores were 2.8 and 3.0 (calculation assumptions: an infinitely rare disease allele, an infinitely polymorphic marker, zero recombination between the marker and the disease allele). Of these 11 families, one was demonstrated to map to DFNB2 and a second identified another locus for ARNSHL, DFNB5 (Fukushima et al. 1995). The remaining nine families were used in this study.

Genomic DNA was prepared from blood samples (Grimberg et al. 1989), and pooled aliquots of DNA from all affected persons in each nuclear family were screened for allelic homozygosity with highly polymorphic markers (Fukushima et al. 1995). Markers were selected by focusing 


\section{RECESSIVE NONSYNDROMIC DEAFNESS: DFNB6}

on regions of high GC content (Antonarakis 1994). When allelic homozygosity was demonstrated with a particular marker, parents and nonaffected siblings were genotyped and haplotypes were reconstructed by typing other polymorphic markers in the region. If results suggested homozygosity by descent, more markers were typed to determine the size of the homozygous interval. Allele sizes were assigned in reference to an M13mp18 sequencing ladder, and genomic DNA from CEPH individual 1347-O2 with known alleles for each marker was typed with all DNA samples.

LOD scores were calculated using the MAPMAKER/ HOMOZ computer package (Kruglyak et al. 1995), setting the frequency of each ARNSHL gene at 0.005 (Morton 1991) and coding the disease as fully penetrant. To guard against inflated LOD scores, the frequency of all homozygous alleles was determined by screening 35 unrelated individuals from the same geographic region and cultural background. A sensitivity analysis also was calculated by imposing a lower band of $10 \%$ on allele frequencies.

\section{ACKNOWLEDGMENTS}

This study was supported in part by the Rotary Club of Iowa City, Okayama, and The International Rotary Foundation (K.F.), and a grant from the Simon and Louise Henderson Foundation (R.J.H.S.). We are grateful to the families from Madras, India, who made this research possible.

The publication costs of this article were defrayed in part by payment of page charges. This article must therefore be hereby marked "advertisement" in accordance with 18 USC section 1734 solely to indicate this fact.

\section{REFERENCES}

Antonarakis, S. 1994. Genomic linkage scanning: systematic or intelligent? Nature Genet. 8: 211-212.

Bailey, A., A.L. Norris, J.P. Leek, P.M. Clissold, I.M. Carr, D.J. Ogilvie, J.F.J. Morrison, D.M. Meredith, and A.F. Markham. 1995. Yeast artificial chromosome cloning of the beta-catenin locus on human chromosome 3p21-22. Chromosome Res. 3: 201-203.

Baldwin, C.T., S. Weiss, L.A. Farrer, A.L. De Stefano, R. Adair, B. Franklyn, K.K. Kidd, M. Korostishevsky, B. Bonné-Tamir. 1995. Linkage of congenital, recessive deafness (DFNB4) to chromosome $7 \mathrm{q} 31$ and evidence for genetic heterogeneity in the Middle Eastern Druze population. Hum. Mol. Genet. 9: 637-642.

Bergstrom, L., W.G. Hemenway, and W.G. Down. 1971. A high risk registry to find congenital deafness. Otolaryngol. Clin. North Am. 4: 369-399.

Calabro, V., G. Pengue, P.C. Bartoli, A. Pagliuca, T. Featherstone, and L. Lania. 1995. Postional cloning of cDNAs fromt he human chromosome 3p21-22 region identifies a clustered organization of zinc-finger genes. Hum. Genet. 95: 18-21.
Chung, C.S. and K.S. Brown. 1970. Family studies of early childhood deafness ascertained through the Clarke School for the Deaf. Am. J. Hum. Genet. 22: 630-644.

Deol, M.S. and M.W. Robins. 1962. The spinner mouse. J. Hered. 53: 133-136.

Fox, S., E.M. Eicher, and S. Reynolds. 1978. Mouse NewsLett. 59: 50.

Friedman T.B., Y. Liang, J.L. Weber, J.T. Hinnant, T.D. Barber, S. Winata, I.N. Arhya, J.H. Asher Jr. 1995. A gene for congenital, recessive deafness DFNB3 maps to the pericentromeric region of chromosome 17. Nature Genet. 9: $86-91$.

Fukushima, K., A. Ramesh, C.R.S. Srisailapathy, L. Ni, A. Chen, M. O'Neill, G. Van Camp, P. Coucke, S.D. Smith, J.B. Kenyon, P. Jain, E.R. Wilcox, R.I.S. Zbar, and R.J.H. Smith. 1995. Consanguineous nuclear families used to identify a new locus for recessive non-syndromic hearing loss on 14q. Hum. Mol. Genet. 9: 643-648.

Grimberg, J., S. Nawoschik, L. Belluscio, R. McKee, A. Turck, and A. Eisenberg. 1989. A simple and efficient non-organic procedure for the isolation of genomic DNA from blood. Nucleic Acids Res. 17: 390.

Guilford, P., S.B. Arab, S. Blanchard, J. Levilliers, J. Weissenbach, A. Belkahia, and C. Petit. 1994a. A non-syndromic form of neurosensory, recessive deafness maps to the pericentromeric region of chromosome 13q. Nature Genet. 6: 24-28.

Guilford, P., H. Ayadi, S. Blanchard, H. Chaib, D. Le Paslier, J. Weissenbach, M. Drira, and C. Petit. 1994b. A human gene responsible for neurosensory, non-syndromic recessive deafness is a candidate homologue of the mouse sh-1 gene. Hum. Mol. Genet. 3: 989-993.

Ibraghimov-Beskrovnaya, O., A. Milatovich, T. Ozcelik, B. Yang, U. Francke, and K.P. Campbell. 1992. Dystroglycan: Tissue distribution, human muscle cDNA, genomic structure and chromosome mapping. Am. J. Hum. Genet. (Abstr.) (Suppl.) 51: A130.

Jiang, C., D. Atkinson, J.A. Towbin, I. Splawski, M.H. Lehmann, H. Li, K. Timothy, R.T. Taggart, P.J. Schwartz, G.M. Vincent, A.J. Moss, and M.T. Keating. 1994. Two long QT syndrome loci map to chromosomes 3 and 7 with evidence for further heterogeneity. Nature Genet. 8: $141-147$.

Kruglyak, L., M. Daly, and E. Lander. 1995. Rapid multipoint linkage analysis of recessive traints in nuclear famiies, including homozygosity mapping. Am. J. Hum. Genet. 56: 519-527.

Li, L., L.-S. Chin, P. Greengard, N.G. Copeland, D.J. Gilbert, N.A. Jenkins. 1995. Localization of the Synapsin II (Syn2) gene to human chromosome 3 and mouse chromosome 6. Genomics 28: 365-366. 


\section{FUKUSHIMA ET AL.}

Morton, N.E. 1991. Genetic epidemiology of hearing impairment. Ann. N.Y. Acad. Sci. 630: 16-23.

Wilkie, T.M., D.J. Gilbert, A.S. Olsen, X.-N. Chen, T.T. Amatruda, J.R. Korenberg, B.J. Trask, P. de Jong, R.R. Reed, M.I. Simon, N.A. Jenkins, and N.G. Copeland. 1992. Evolution of the mammalian $G$ protein alpha subunit multigene family. Nature Genet. 1: 85-91.

Received June 26, 1995; accepted in revised form September 26, 1995. 


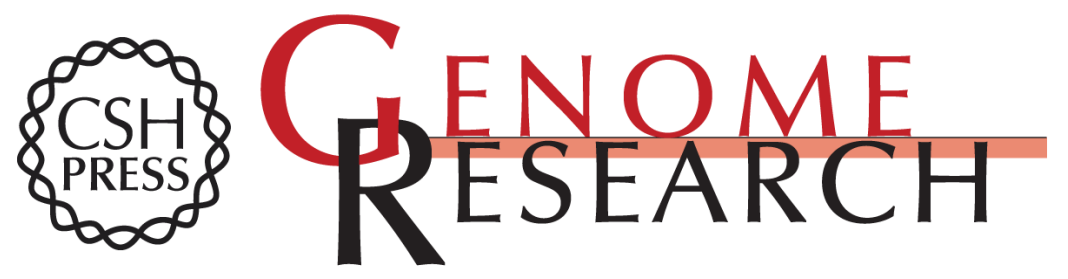

\section{An autosomal recessive nonsyndromic form of sensorineural hearing loss maps to 3p-DFNB6.}

K Fukushima, A Ramesh, C R Srisailapathy, et al.

Genome Res. 1995 5: 305-308

Access the most recent version at doi:10.1101/gr.5.3.305

\section{License}

Email Alerting Service
Receive free email alerts when new articles cite this article - sign up in the box at the top right corner of the article or click here.

\section{Affordable, Accurate Sequencing.}

